\title{
Significance of a Nursing Program for Mental Health Assessment and Psychological Care of Cancer Patients
}

\author{
Mariko Kaneko*, Professor,PhD,RN,CNS \\ Tokyo Health Care University, Japan
}

Submission: May 08, 2017; Published: May 25, 2017

*Corresponding author: Mariko Kaneko, Tokyo Health Care University, Japan, Email: m-kaneko@thcu.ac.jp

Aim

The purpose of this study was to develop and evaluate the mental health assessment, psychological care, and stress management skills of the nurses caring for cancer patients.

Keywords: Psycho-oncology; Nursing education program; Mental health assessment; Psychological care

\section{Introduction}

Do nurses possess sufficient knowledge and skills to assess the mental health and psychological characteristics of cancer patients? Approximately one-third of cancer patients suffer from a psychiatric disorder [1]. Care providers frequently dismiss depression and low-mood status of cancer patients; however, a recent study showed that over $50 \%$ of nurses involved in cancer care were "very concerned" about assessing anxiety and depression in cancer patients and approximately 20\% were "extremely concerned" about caring for patients experiencing depression and anger. These nurses were clearly aware of limitations in their knowledge and skills regarding caring for cancer patients with mental health issues [2]. Influence of depression should be carefully considered when interpreting quality-adjusted life years for cancer patients [3].

\section{Method}

From October 2016 to January 2017, I conducted an educational program and trained 20 cancer care nurses to deliver mental health and psychological caret o cancer patients. The educational program was developed based on previous research and internet survey results [4]. The $10 \mathrm{~h}$ program focused on assessing the mental and psychological health of cancer patients, communication skills, and decision-making. Additionally, nurses were trained for their own stress management.

\section{Statistical Analysis}

All nurses completed a self-administered survey at the following time points: before the program, immediately after the program, and 3 months after the program. The survey assessed nurses' knowledge and skills relating to the assessment of mental health in cancer patients. The nurses responded on a four-level Likert scale. Data were analyzed using Wilcoxon signed-rank test with SPSS software Ver. 22.

\section{Result}

The effective response rate was $14(70 \%)$. Of the 10 aspects of mental health care that were assessed, 9 items displayed validity before and 3 months after the educational program. Regarding anxiety in cancer patients, knowledge, practical aspects of self-efficacy regarding knowledge and practice were low effectiveness was also recognized in decision-making and nurse's own stress management.

\section{Consideration}

Canadian Strategy for Cancer Control recommends that emotional distress be considered the sixth vital sign [5]. It is important to train cancer care nurses for providing mental health assessment and psychological care to cancer patients. The timing of the mental health educational program is more appropriate than that of the standard undergraduate nursing curricula in terms of the nurse's readiness to apply the education received during training to the challenges they face during daily practice. Future efforts should continue to strengthen mental health education for nurses, possibly by incorporating a crossdisciplinary collaborative training model. 


\section{Acknowledgment}

This work was supported by MEXT KAKENHI Grant Number 26463357

\section{References}

1. Bringmann H, Singer S, Höckel M, Stolzenburg JU, Krauss O, et al (2008) Longitudinal analysis of psychiatric morbidity in cancer patients. Onkologie 31(6): 343-344.

2. Kaneko M, Ryu S, Nishida H, Tamasato K, Shimodaira Y, et al. (2012) Nurses' recognition of the mental state of cancer patients and their own stress management - a study of Japanese cancer-care nurses. Psychooncology 22(7): 1624-1629.

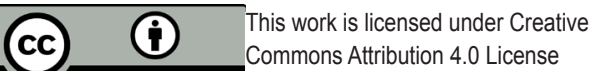

3. Fujisawa D, Inoguchi H, Shimoda H, Yoshiuchi K, Inoue S, et al. (2016) Impact of depression on health utility value in cancer patients. Psychooncology 25(5): 491-495.

4. Kaneko M, Ryu S, Koyama M, Kakeh R (2016) Perspectives and challenges in the psychological care of cancer patients and in stress management for oncology nurses: an online survey among Japanese nurses. Int Arch Nurs Health Care 2(1): 2469-5823.

5. Bultz BD, Carlson LE (2016) Emotional Distress: The Sixth Vital Sign in Cancer Care. J Clin Oncol 23(26): 6440-6441.

\section{Your next submission with Juniper Publishers will reach you the below assets}

- Quality Editorial service

- Swift Peer Review

- Reprints availability

- E-prints Service

- Manuscript Podcast for convenient understanding

- Global attainment for your research

- Manuscript accessibility in different formats

( Pdf, E-pub, Full Text, Audio)

- Unceasing customer service

Track the below URL for one-step submission https://juniperpublishers.com/online-submission.php 